\title{
Hybrid Dispute Resolution in Islamic Capital Market: A Malaysian Perspective
}

Naeem Suleman Dhiraj, Muhammad Najihuddin Nasucha, Oussama Mohamed Alansary, and Abdullah Jamaluddin Alkhateeb International Islamic University Malaysia (IIUM)

\begin{abstract}
:
The objective of this paper is to explore dispute resolution mechanisms in the Islamic capital market. This paper examines out of court traditional dispute resolution mechanisms and innovative hybrid mechanisms for dispute resolution which could be more efficient and less time-consuming. This paper also looks at notable legal disputes relating to the Islamic capital market for the purpose of understanding the procedural challenges and inadequacies in the current legal system. Based on a literature review the authors of this paper note that the majority of Islamic capital market disputes could be resolved through alternative dispute resolution without going through a full trial in court. This paper mainly focuses on the context of Malaysia, with minor references to other countries.
\end{abstract}

Keywords: Islamic Banking Dispute; Malaysia; Islamic Capital Market; Alternative Dispute Resolution 


\section{Introduction}

Malaysia is one of the largest hubs for Islamic banking and finance. The concept of Islamic banking and finance began in the 1930s and has progressed significantly and consistently since then. The first Islamic bank in Malaysia, Bank Islam Malaysia, was established in 1983 (Al Nasser and Muhammed, 2013). With the rise of Islamic banking in the country and the need to increase efficiency and effectiveness in banking, more and more companies began to source funding from the Islamic capital market, especially since the 1990s (ISRA, 2015). The Islamic capital market allows fund seekers to mobilise funds and enables investors to diversify their portfolios, thereby enhancing the liquidity of the Islamic financial system. It provides a stable source of funding to finance capital intensive infrastructure development, serving the financial interests of both public and private sectors (Oseni, 2014).

Being a market leader in Islamic banking and finance sector, the Malaysian government has made significant progress in promoting and regulating the sector. The Islamic Capital Market is an integral part of Islamic banking and finance that bridges fund seekers and capital providers. It consists of asset-backed securities, equity-based securities, and Islamic bonds (sukuk). However, the complexities of Islamic financial transactions give rise to disputes and conflict between the contracting parties which often results in legal actions. These legal actions could be in the form of litigation, a formal adjudication process inside the court; at times, the parties choose to resolve their dispute outside court through a process called Alternative Dispute Resolution (ADR) which includes arbitration, mediation, or negotiation. However, little is known about the use of dispute resolution mechanisms in the Islamic capital market. The purpose of this paper is thus to explore the arbitration and mediation used in Islamic banking in general and in the Islamic capital market in particular.

\section{Litigation}

As the complexities of Islamic financial transactions increase, more disputes are being litigated. In Malaysia, most Islamic banking disputes are decided through litigation, before the civil courts (Trakic, 2019). Parties, however, do not consciously choose to litigate as their first choice for dispute resolution; instead, it is more a customary practice or default mode (Markom and Yaakub, 2012).

Islamic finance disputes revolve around contractual interpretation (Trakic, 2019; Oseni et al., 2016). The underlying contract is the bedrock of every financial transaction. The governing law and jurisdiction clause is a major determinant of the way and manner a dispute arising out of such a contract will be resolved (Oseni et al., 2016). The terms of such clauses often lead to controversy or legal disputes as a result of differences between Shariah law and the legal system. The existing legal framework for dispute resolution in the Islamic finance industry is inadequate (Engku Ali, 2008; Markom and Yaakub, 2012; Oseni et al., 2016). Mainly, this is due to the uncertainty surrounding the nature of Shariah law (Oseni et al., 2016) and a lack of consensus between schools of Islamic jurisprudence on the validity of certain Islamic financial contracts (e.g. Bay Salam).

International Journal of Management and Applied Research, 2019, Vol. 6, No. 4 
English law has been the preferred law of choice for the parties involved in crossborder Islamic finance transactions (Trakic, 2013). Parties who are more familiar with English law and courts find friendlier mechanisms of commercial arbitration specialising in Islamic finance (Colon, 2011, p. 435). In countries that are not legally influenced by Islamic law, courts have had success in judging Shariah issues in Islamic financial transactions through the use of expert opinions or consultation (Colon, 2011; Markom and Yaakub, 2012). The litigation process in Islamic banking and finance is handled similarly to other disputes, which causes controversy. Oseni et al. (2016) consider that the current practices of litigation do not fit the very nature of Islamic financial services industry because current banking and financial litigation is based on the conventional finance industry, which is fundamentally different from the Islamic finance industry.

\section{Alternative Dispute Resolution}

Alternative dispute resolution is commonly referred to as a peaceful solution to the conflict out of court. The use of arbitration in Islamic law is largely influenced by the evolution of alternative dispute resolution in Western jurisdiction and the Ottoman legal code (Oseni 2015). Although the term "Alternative Dispute Resolution" is not commonly used in Islamic sources, Oseni and Ahmad (2016) noted that there are numerous references to amicable resolution of disputes in handling Islamic finance disputes, including Nasihah (counselling), Sulh (mediation), Tahkim (arbitration), Muhtasib (ombudsman), Wali al-Mazalim (chancellor or ombudsman judge), and Fatwa of Mufti (expert determination). Mediators in traditional hierarchical society were always people in positions of authority; however, indigenous forms of mediation became less common, partly due to modernisation and westernisation (Lee, 2018).

The varieties of dispute resolution processes evolved over time and transformed across Muslim communities. These dispute resolution processes were used in different forms, without escalating to a formal tribunal (Oseni 2015). According to Oseni and Ahmad (2016), dispute resolution in Islamic law includes a range of processes for amicable resolution of disputes, namely, court-annexed arbitration, out-of-court-settlement by a third-party who is capable of making neutral and objective judgements. Oseni (2015) noted that there is a gradual return to the classical means of dispute resolution in modern days, especially in countries like Malaysia, Singapore, and Middle East and North African (MENA) countries.

However, Islamic banks seem to prefer litigation over alternative dispute resolution mechanisms, especially in the event of default (Oseni and Ahmad, 2016; Trakic, 2019). Mainly, this is because they are more concerned with the profits and risks involved in financial transactions and thus seek settlement in court (Oseni and Ahmad, 2016). One major problem is that, civil courts tend to decide Islamic banking disputes based on civil laws and treat Islamic financial contracts as loan agreements (Trakic, 2013), without considering the underlying Shariah aspects of contractual agreement. This is mainly due to the fact that the judges and legal counsels at the civil courts were not exposed to Shariah law and Islamic banking concepts, especially during the

International Journal of Management and Applied Research, 2019, Vol. 6, No. 4 
introductory stage of the industry in the 1990s (Oseni and Ahmad, 2016). For this reason, civil court judges are deemed unsuited for adjudicating Shariah issues in Islamic financial disputes by scholars (Markom and Yaakub, 2012; Oseni and Ahmad, 2016; Trakic, 2019). In Malaysia, the Shariah aspects of Islamic finance contract are given recognition and enforcement in both litigation and arbitration (Trakic, 2019). The dispute resolution process in the Shariah court is not free from challenges, however. In Malaysia, the court-annexed alternative dispute resolution in the Shariah court faces challenges such as inadequate staff, insufficient facilities, rescission of settlement agreement, and inconsistent practice of alternative dispute resolution (Oseni, 2015).

\subsection{Mediation}

Mediation is an informal voluntary alternative dispute resolution process. Essentially, it involves the participation of a neutral third party who assists the disputing parties in reaching the resolution. The third party or mediator does not decide for them and the decision making is left entirely to the parties. They may conclude the mediation process with a formal contract of agreement between them. In Islamic law, sulh is a generic term which includes mediation, conciliation and good faith negotiation (Oseni and Ahmad, 2016).

The Malaysian judiciary has shown a strong commitment and support for courtannexed mediation (Trakic, 2019). The Chief Justice of Malaysia issued a Practice Direction on mediation, which came into effect on 16 Aug 2010. The objective of Practice Direction on mediation is to encourage the parties to amicably arrive at an early settlement, without going through a complete trial or appeal. The civil courts in Malaysia are encouraged to consider the option of mediation in all cases coming before them as outlined in Practice Direction No 5 of 2010 on Mediation. The Practice Direction offers two modes of referral to mediation; Judge-led mediation or an appointment of a mediator agreeable to both parties. The Shariah Advisory Council of Bank Negara may assist the court in identifying experts or scholars in the field of Islamic finance who will sit to mediate exclusively upon Islamic finance disputes (Oseni and Ahmad, 2016).

\subsection{Arbitration}

As in other legal systems, arbitration in Islamic law is based on the mutual consent of the disputing parties, by submitting a dispute to a third-party who is neutral and objective (Oseni, 2015). Settling Islamic finance disputes outside the court is less controversial because the court is not bound to apply court of law. As Colon (2011, p. 429) reported: "Enforcement of Islamic arbitration awards has proven to be relatively uncontroversial in U.S. courts. More compelling is that the application of Islamic Law is not out of bounds for a U.S. court to apply".

Accounting and Auditing Organisation for Islamic Financial Institutions (AAOIFI), a standards body that issues Shariah standards for Islamic finance, issued Shariah Standard No. 32 on Tahkim (Arbitration) in order to introduce dispute management that is in line with Shariah principles when settling Islamic banking disputes (AAOIFI,

International Journal of Management and Applied Research, 2019, Vol. 6, No. 4 
2008). This Standard can function as a general reference when dealing with disputes in the Islamic capital market.

In Malaysia, the Arbitration Act 2005 came into effect on 14th of March 2006. iArbitration Rules 2013 was enacted for international commercial arbitration disputes with Shariah law issues. The rule provides for the logistics of deciding how the costs will be distributed, choosing who will review Shariah law, and whether the arbitral tribunal can continue with non-Shariah issues while the Shariah expert or council make their determinations. By virtue of sections 56 and 57 of the Central Bank Malaysia Act 2009 , the civil court judges or arbitrators are obliged to refer Shariah issues to the Shariah Advisory Council, the highest authority for ascertainment of Shariah aspects relating to Islamic banking and finance.

Kuala Lumpur Regional Centre for Arbitration (KLRCA) is a dispute resolution body providing institutional support for domestic and international arbitrations. Established in 2007, the main goal of KLRCA (www.klrca.org) is to encourage the use of arbitration for disputes emanating from Islamic financial services. However, there has been an alarmingly low number of Islamic finance cases arbitrated over the past decade; according to Oseni and Ahmad (2016), there were only two cases arbitrated between 2007 and 2016.

\section{Causes of Disputes}

Disputes in the Islamic capital market arise for a myriad of reasons, below are some potential causes of dispute.

\subsection{Default in Payment}

Default is a failure to meet the financial commitments or legal obligations of a loan. The issue of default is of great concern in the banking sector, especially in Islamic banking. The prohibition of riba under Shariah applies to all forms of interest, including a fixed penalty on late repayment (Hasan et al., 2019). Bank Negara Malaysia (2010) provides guideline to Islamic financial institutions on the mechanism of late payment charges. The Shariah Advisory Council of Bank Negara Malaysia resolved that the imposition of late payment charges by Islamic banking institutions which comprise both the concepts of gharamah (fine or penalty) and ta'widh (compensation) is permissible (Bank Negara Malaysia, 2010).

In the Islamic capital market, the issue of default is equally of great concern because it affects the confidence and welfare of shareholders. Sukuk (Islamic bond) default occurs when the sukuk issuer fails to make periodic schedule payments to the sukuk holders (Oseni, 2014). This would normally lead to an extension of the maturity of sukuk and sukuk holders experience loss of opportunity cost and time-value of money (Alam et al., 2018). To attract global investors to participat in Islamic capital market, sukuk issuers can learn from the advances of the conventional bond market in managing default risks. Sukuk defaults such as Nakheel, Tamweel and Gold Belt Sukuk raise concerns about the viability of sukuk as an alternative source of investment (Alam et al., 2018). In the event of default, resort must be made to the

International Journal of Management and Applied Research, 2019, Vol. 6, No. 4 
underlying Islamic financial contracts and the governing law for each contract in the string of contracts (Oseni, 2014). The prohibition of riba also restricts short-term interbank lending from the central bank for sukuk issuers (Hasan et al., 2019), therefore limiting the development of a liquid secondary market for Sukuk. The main strategy in dealing with a default of a sukuk transaction is to initiate a debt restructuring mechanism, such as having constructive negotiations with sukuk holders with a common goal of reaching a consensual restructuring that would add value to all the stakeholders (Oseni, 2014).

\subsection{Breach of Contract}

The root cause of Islamic banking disputes lies in the way the Islamic finance contract is drafted (Oseni et al., 2016). A breach of contract occurs when a contracting party fails to fulfil his or her contractual obligation. Sukuk default may also take place when there is a breach of any fiduciary responsibilities or binding obligations under the original terms of the agreement between sukuk issuer and sukuk holders (Hasan et al., 2019).

Dana Gas sukuk default is an exemplar here. On June 2016, United Arab Emiratesbased energy producer Dana Gas announced to its creditors that two of its sukuk issued on 31 October 2013 for a total of $\$ 700$ million were not compliant with Shariah principles which prohibit riba, and thus it would be unlawful to repay its sukuk holders (Hasan et al., 2019). A group of sukuk holders challenged the action in the English court, and the English High Court ruled in favour of the sukuk holders in November 2017 and upheld this verdict in February 2018 (Smith, 2018). Busari et al. (2019, p. 581) concluded that the English Court decision is fair because the ruling is based on Islamic legal maxims such as "difficult situation cannot violate the right of other", "every difficulty must be eliminated", and the conditional matters among Muslims are binding.

\section{Hybrid Alternative Dispute Resolution in Islamic Capital Market}

According to Oseni (2014), there is a number of amicable dispute resolution processes that are applicable in insolvency disputes, namely sulh (mediation or conciliation in Islamic law), arbitration (tahkim) and court adjudication (qada). Both mediation and arbitration offer advantages to the disputing parties. While mediation has high settlement and high compliance rates, arbitration has speedy settlements compared to adjudication (Ross and Conlon, 2000). Combining mediation and arbitration into one process, on the other hand, offers the disputing parties the opportunity to structure and control their own resolution and also a certainty that their dispute will be resolved with a final binding award if the parties fail to settle in mediation (Deason, 2013). The following section looks at mediation-arbitration, arbitration-mediation, and combination of mediation and expert determination.

\subsection{Mediation-Arbitration (Med-Arb)}

Mediation-arbitration (med-arb) consists of two phases: (1) it starts with standard procedures of basic mediation and proceeds to (2) arbitration only if mediation fails in reaching a settlement. The disputing parties retain decision control and exercise

International Journal of Management and Applied Research, 2019, Vol. 6, No. 4 
process control during the mediation phase; they only relinquish decision control at the end of the process (Ross and Conlon, 2000). Med-arb is likely to be less costly and time-consuming than other dispute resolution mechanisms such as arb-med because the dispute is likely to be settled in mediation (Ross and Conlon, 2000).

A combination of sulh (mediation) and tahkim (arbitration) may also be used in resolving Islamic finance disputes (Chung, 2016; Rasyid, 2013). The med-arb process was practiced in Islamic legal history (Chung, 2016). Through this combined process, the Islamic financial institution and its customers could settle their disputes through sulh assisted by a neutral third party in reaching a voluntary agreement. If this stage fails, they could then proceed to a binding arbitration. Islamic finance disputes could be resolved quickly through med-arb, thus reducing costs and time to settle. Rasyid (2013) found that the practice of the Financial Mediation Bureau (FMB) in Malaysia is similar to that of Med-Arb because the mediator of FMB can give an award if an amicable settlement cannot be reached.

\subsection{Arbitration-Mediation (Arb-Med)}

Arbitration-mediation (arb-med) consists of three phases (Ross and Conlon, 2000). The first phase is an arbitration hearing conducted by an independent third party or an arbitrator. At the end of this phase, the third party formulates an award, without sharing it with the parties. A common practice is to place it in a sealed envelope (Deason, 2013). The second phase consists of mediation in which the disputing parties mediate the dispute. If their dispute is mediated successfully, their agreement is the outcome of the process (Deason, 2013). If they are unable to reach an agreement, the parties then proceed to the third phase in which the sealed envelope is to be opened (Ross and Conlon, 2000) and the award becomes binding (Deason, 2013). These three phases of arbitration-mediation-arbitration address the concerns of the disputing parties such as the enforceability of the outcome and uncertainty whether mediation will yield an outcome (Lee, 2018). The Singapore International Arbitration Centre (SIAC) and Singapore International Mediation Centre (SIMC) refer such process as "Arb-Med-Arb" Protocol (AMA Protocol). The AMA Protocol provides a framework in conducting arb-med-arb process, including an 8-week maximum timeframe within which mediation must be conducted and completed (Singapore International Mediation Centre, 2019).

Records of combining sulh (mediation) and tahkim (arbitration) can be found in the literature (Chung, 2016; Oseni and Ahmad, 2016; Rasyid, 2013); however, little is known about the use of arb-med or arb-med-arb in Islamic banking and finance.

\subsection{Mediation-Expert (Med-Ex)}

A combination of mediation and expert determination (med-ex) is a hybrid dispute resolution model which could be used to settle Islamic finance dispute. According to Yaacob (2012), med-ex places mediation in the first stage and expert determination in the second. In this hybrid model, an independent third party or the mediator assists the disputing parties in reaching their disputes. The third party summarises the disputed issues, develops options, considers alternatives and proposes a mechanism to reach an amicable agreement. Similar to med-arb, the disputing parties only proceed to the

International Journal of Management and Applied Research, 2019, Vol. 6, No. 4 
second stage (expert determination) if the first stage (mediation) fails. Oseni and Ahmad (2016) claimed that med-ex may be the best bet for the existing court-annexed mediation in the High Court of Malaysia.

According to Yaacob (2012), expert is the determination or opinion of the expert known as "al-ra'yu al-khabir." In the Arabic language, the first word al-ra'yu means opinion or determination, while the second is derived from khabara which has several meanings such as to inform, to try, to examine and to know something thoroughly. When it becomes a term, al-ra'yu al-khabir means the testimony of a person skilled in a specific field (Yaacob, 2012). It is evident that the concept of al-ra'yu al-khabir resembles the concept of the expert witness in the regular court process. In the case of failure to reach any consensus, an expert on Islamic finance will be involved to make a determination or give an opinion regarding the dispute and the settlement. The expert here can be an individual who has an in-depth understanding of the field or a group of people deliberating on the same case. The role of expert here resembles the role of fatwa issued by mufti (expert determination) (Oseni and Ahmad, 2016; Rasyid, 2013).

\subsection{Dispute resolution mechanism in Islamic capital market}

In addition to the legal system, the operations and the participants in the Islamic capital market must comply with Shariah law. Consequently, in dealing with disputes arising in the Islamic capital market, the mediator or arbitrator must not only follow common law legal systems but also take Islamic law into consideration. Oseni (2014) highlighted that there should be more effective mechanisms to resolve sukuk default cases and these mechanisms should be structured in a way that ensure Shariah compliance and address issues relating to legal enforceability of a decision or negotiated settlement. Such mechanisms may include mediation, negotiation or expert assessment by a neutral third party specialising in Islamic bonds and securities (Oseni, 2014).

Islamic law has introduced a number of amicable dispute settlement mechanisms, namely muhtasib (ombudsman), wali al-mazalim (chancellor or ombudsman judge), and fatwa issued by mufti (expert determination). In Islamic banking and finance disputes, a mufti can be asked by the disputing parties to give a fatwa (Rasyid, 2013). It is similar to expert determination where the disputing parties entrust the dispute to an expert for evaluation regarding the technical nature of the dispute. Typically, the expert identifies the causes of dispute and sources of Shariah non-compliance. If one party is found responsible for misconduct or breach of contract, the expert can exercise his judge (qadhi)-like authority to declare bankruptcy or taflis and all of its consequences (al-Mishry, 1982). The same treatment also applies to disputes driven by breach of contract. In addition to looking into the factors driving one party to breach the contract, the expert will examine the possibility of a particular contract being transformed into another contract, as well as external sources which are beyond the control of the disputing parties.

Oseni (2014) proposed the option of a more formal amicable dispute resolution platform such as the Shariah arbitration tribunal in settling sukuk default. This

International Journal of Management and Applied Research, 2019, Vol. 6, No. 4 
certainly adds enforceability to the award in order to protect financial consumers and the rights of the stakeholders.

\section{Conclusion}

Regulation is a key to sustainable growth in any industry, especially when the key stakeholders look beyond financial interests and aim to achieve best practices. With the growing interest in the Islamic capital market, there is a need to enhance regulatory regimes and revise regulations in most jurisdictions. Recent reforms in Singapore and Malaysia, where the traditional dispute settlement processes have been modernised, serve as good basis for adaptation of best practices in other countries. As Oseni (2014) concluded, global investors prefer jurisdictions that have a robust regulatory framework in line with global best practice.

The Islamic capital market is vulnerable to Shariah non-compliance and default risk, as shown in the cases of Nakheel and Dana Gas sukuk default. Hybrid dispute resolution is a novel mechanism for resolving banking disputes. This study examines the hybrid process of arbitration and mediation in Islamic banking and finance and explores dispute resolution mechanism in the Islamic capital market. This paper mainly focuses on the context of Islamic capital market in Malaysia; future studies could compare dispute resolution processes in Malaysia and Singapore in depth because both are global financial hubs. Moreover, future studies could study the socio-cultural implications of settling banking disputes in both countries.

\section{References}

1. Accounting and Auditing Organisation for Islamic Financial Institutions (AAOIFI) (2008), Shariah Standards, Bahrain: AAOIFI.

2. Alam, N., Bhatti, M. and Wong, J. (2018), “Assessing Sukuk defaults using valueat-risk techniques", Managerial Finance, Vol. 44 No. 6, pp. 665-687. https://doi.org/10.1108/MF-05-2018-0218

3. Arbitration Act 2005

4. Al-Mishry, A. N. (1982), Úmdat al-Salik wa Úddat al-Nasik, Doha: Syuun Diniyyah.

5. Al Nasser, S. A. S., and Muhammed, D. D. J. (2013), "Introduction to history of Islamic banking in Malaysia", Humanomics, Vol. 29 No. 2, pp. 80-87. https://doi.org/10.1108/08288661311319157

6. Bank Negara Malaysia (2010), Shariah Resolutions in Islamic Finance, 2nd ed. Kuala Lumpur: Bank Negara Malaysia.

7. Busari, S., AbdulAziz, A., Zakariyah, L. and Amanullah, M. (2019), "Dana Gas Sukuk default: a juristic analysis of court judgement", International Journal of

International Journal of Management and Applied Research, 2019, Vol. 6, No. 4 
Islamic and Middle Eastern Finance and Management, Vol. 12 No. 4, pp. 569-585. https://doi.org/10.1108/IMEFM-01-2019-0033

8. Central Bank Malaysia Act 2009

9. Chung, Y. (2016), "Combining Arbitration with Mediation: Two Cultures of China and Malaysia”, Journal of Arbitration Studies, Vol. 26, No. 3, pp. 149-174.

10. Colon, J. C. (2011), "Choice of Law and Islamic Finance", Texas International Law Journal, Vol. 46, pp. 411-435.

11. Deason, E. E. (2013), "Combinations of Mediation and Arbitration with the Same Neutral: A Framework for Judicial Review”, Arbitration Law Review, Vol. 5, pp. 219-249.

12. Engku Ali, E. R. (2008), "Constraints and opportunities in harmonisation of civil law and Shariah in the Islamic financial services industry", Malayan Law Journal, Vol. 4, pp. i-xxxvii.

13. Hasan, R., Ahmad, A. and Parveen, T. (2019), "Sukuk risks - a structured review of theoretical research", Journal of Islamic Accounting and Business Research, Vol. 10 No. 1, pp. 35-49. https://doi.org/10.1108/JIABR-06-2015-0026

14. International Shariah Research Academy (ISRA) (2015), Islamic Capital Markets: Principles and Practices, Kuala Lumpur: International Shariah Research Academy, Malaysia.

15. $i$-Arbitration Rules 2013

16. Lee, J. (2018), "Cultural Influences in the Historical and Institutional Development of Mediation”, in: Stobbe, S. P. (Eds), Conflict Resolution in Asia: Mediation and Other Cultural Models, USA: Lexington Books, pp. 107-132.

17. Markom, R. and Yaakub, N. I. (2015), "Litigation as dispute resolution mechanism in Islamic finance: Malaysian experience", European Journal of Law and Economics, Vol. 40, No. 3, pp. 565-584. https://doi.org/10.1007/s10657-012-9356$\mathrm{x}$

18. Oseni, U. (2014), "Dispute management in Islamic financial institutions: a case study of near sukuk defaults", Journal of International Trade Law and Policy, Vol. 13 No. 3, pp. 198-214. https://doi.org/10.1108/JITLP-12-2013-0034

19. Oseni, U. (2015), "Sharī'ah court-annexed dispute resolution of three commonwealth countries - a literature review", International Journal of Conflict Management, Vol. 26 No. 2, pp. 214-238. https://doi.org/10.1108/IJCMA-062012-0050

20. Oseni, U. and Ahmad, A. (2016), "Towards a global hub: The legal framework for dispute resolution in Malaysia's Islamic finance industry", International Journal of

International Journal of Management and Applied Research, 2019, Vol. 6, No. 4 
Law and Management, Vol. 58, No. 1, pp. 48-72. https://doi.org/10.1108/IJLMA08-2014-0052

21. Oseni, U. O.; Adewale, A. and Mohd Zain, N. R. (2016), “Customers' perceptions on the dispute resolution clauses in Islamic finance contracts in Malaysia", Review of Financial Economics, Vol. 31, pp. 89-98. https://doi.org/10.1016/j.rfe.2016.05.004

22. Rasyid, A. (2013), "Relevance of Islamic dispute resolution processes in Islamic banking and finance", Arab Law Quarterly, Vol. 27, No. 4, pp. 343-370.

23. Ross, W. H., and Conlon, D. E. (2000), "Hybrid Forms of Third-Party Dispute Resolution: Theoretical Implications of Combining Mediation And Arbitration", Academy of Management Review, Vol. 25, No. 2, pp. 416-427. https://doi.org/10.2307/259022

24. Singapore International Mediation Centre (2019), SIAC-SIMC Arb-Med-Arb Protocol, [Online] Available from: http://simc.com.sg/v2/wpcontent/uploads/2019/03/SIAC-SIMC-AMA-Protocol.pdf [Accessed on 14 December 2018].

25. Smith, R. (2018), "Dana Gas strikes restructuring deal to end sukuk dispute", Financial Times, [Online] Available from: https://www.ft.com/content/83ace1c256a4-11e8-b8b2-d6ceb45fa9d0 [Accessed on 14 December 2018].

26. Trakic, A. (2019), "Settlement of Islamic finance disputes in Malaysia", in: Trakic, A.; Benson, J. and Ahmed, P. K. (Eds) Dispute Resolution in Islamic Finance: Alternatives to Litigation?, London: Routledge, pp. 94-119.

27. Trakic, A. (2013), "The adjudication of Shari'ah issues in Islamic finance contracts: Guidance from Malaysia”, Humanomics, Vol. 29, No. 4, pp. 260-275. https://doi.org/10.1108/H-05-2012-0011

28. Yaacob, H. (2012), Alternative Dispute Resolution (ADR): Expanding Options in Local and Cross Border Islamic Finance Cases, Kuala Lumpur: International Shari'ah Research Academy for Islamic Finance.

International Journal of Management and Applied Research, 2019, Vol. 6, No. 4 